\title{
A SEREIAZINHA SURDA: UMA ADAPTAÇÃO LITERÁRIA
}

\section{THE DEAF LITTLE MERMAID: A LITERARY ADAPTATION}

Kátia Nascimento*

\section{Resumo}

Este artigo descreve o processo de adaptação do conto "A Sereiazinha" de Andersen, em conformidade com a proposta de ajustá-lo ao contexto da cultura surda. O principal objetivo desta pesquisa foi o de experienciar o processo de adaptação literária, para melhor compreendê-lo. Procurou-se também colaborar para a ampliação do acervo da Literatura Surda, que ainda se apresenta muito reduzido, com a produção de um novo texto. As principais referências teóricas foram Carvalho, Huston e Karnopp. A metodologia embasou-se nesse referencial teórico e na análise de outras obras anteriormente adaptadas para a Cultura Surda. Ao final, concluiu-se que novas produções de Literatura Surda, assim como sua propagação, favorecem o reconhecimento dos surdos como um grupo cultural com identidade própria.

Palavras-chave: Literatura surda. Andersen. Adaptação literária.

\section{Introdução}

As histórias infantis são ficções cercadas de questões existenciais nas quais a criança pode embasar-se e encontrar respostas aos seus questionamentos e conflitos interiores. Esse processo auxilia na percepção e escolha de valores que construirão sua personalidade e subjetividade, promovendo seu crescimento como ser social e cultural. Os valores morais e os comportamentos padrão dos indivíduos os faz perceberem-se como semelhantes e moldaremse como um grupo, uma sociedade, com costumes próprios. É esse padrão social que define o

\footnotetext{
* Especialização em Educação Especial na Perspectiva do AEE pela Faculdade Delta. Licenciatura em Letras Libras pela Universidade Federal de Goiás - UFG, Pedagogia e Biologia pela Universidade Estadual Vale do Acaraú- UEVA. E-mail: ksnascimento@yahoo.com
} 
que é certo ou errado, o que é "normal" e o que é diferente, pois aquilo que foge às regras é rejeitado e excluído.

Os personagens das narrativas infantis apresentam ações e comportamentos distintos, cabendo à criança identificar e reconhecer os valores que auxiliem no seu processo de construção individual. A admiração pelo herói faz com que a criança se identifique com ele e com o objetivo de suas lutas, fazendo-a sentir-se representada e preparada para reproduzir suas ações. De acordo com Bettelheim (2002), é esse personagem quem responde à sua pergunta sobre com quem ela quer se parecer e qual caminho deve seguir. Portanto, a criança não busca uma escolha entre ser boa ou má, mas um referencial no qual ela se reconheça.

Para Bettelheim (2002, p. 77), a criança leitora "que se sente condenada a ser um patinho feio não precisa se desesperar, crescerá para ser um lindo cisne". Mas o que fazer quando, ao conhecer a história, a criança não se reconhece como o patinho diferente a espera de ser metamorfoseada em cisne, mas, ao contrário, sente que é essa diferença que a define? Como entender que ela deva aderir a costumes diferentes daqueles que ela vivencia?

Apesar das conquistas alcançadas, essa ainda é a realidade do ser surdo ante a massiva comunidade ouvinte: a luta para não ser moldado por uma cultura alheia. Para viverem a inclusão social, muitos surdos sucumbem à cultura dos ouvintes, submetendo-se às soluções para a surdez do ponto de vista patológico. Apropriam-se dos costumes do ouvinte não por escolha, mas por não encontrarem seu próprio espaço, se sentindo camuflados em um ambiente alheio, necessitando se adequar a este e abandonar suas origens.

Essa conjuntura é incoerente, visto que, nos dias atuais, o surdo é, reconhecidamente, detentor de uma língua própria, de costumes e de uma história. Isso o torna livre para assumir sua identidade e difundir sua cultura. E a literatura surda é uma poderosa ferramenta capaz de viabilizar o alcance desses objetivos. Apesar disso, o acervo literário direcionado às crianças surdas ainda é muito reduzido e, embora a literatura produzida para crianças ouvintes ofereça a mesma base de valores morais a todas as crianças, ouvintes e surdas, os aspectos culturais do ouvinte envolvem, intrinsecamente, as características da fala e da audição, enquanto o sujeito surdo se utiliza da percepção viso-espacial para compreender o mundo que o cerca.

Os referenciais ficcionais do povo ouvinte podem gerar, portanto, questionamentos, insatisfação e sentimento de opressão e imposição da cultura majoritária. Por outro lado, a experiência literária no viés da própria cultura instiga, além do interesse pela leitura, a identificação com suas origens, contribuindo para a construção da identidade da criança. Para 
Corso e Corso (2007, p. 16), "toda a criança conhece a experiência de sentir-se uma "estranha no ninho". Ouvir histórias é um dos recursos de que as crianças dispõem para desenhar o mapa imaginário que indica seu lugar, na família e no mundo". Desse modo, produzir e adaptar a literatura para o universo da criança surda garante seu direito de vivenciar a experiência da leitura dentro de sua esfera cultural.

Huston (2010, p. 20) afirma que "seres humanos são mágicos sem se darem conta disso". Ao contar uma história para crianças, é preciso, antes de tudo, ter ciência que o contador de histórias, se torna, assim como os personagens desta, um referencial para os que a ouvem. Ele é o personagem real que vai comprovar que as palavras ditas refletem os valores que carrega. É a ficção se tornando realidade para quem ainda está construindo sua identidade. Para Huston (2010), o "eu” é uma construção elaborada por camadas e camadas de narrativas. A construção da identidade, segundo Huston (2010, p. 64), ocorre a partir das histórias inculcadas ao longo dos primeiros anos de vida. "As primeiras marcas - língua materna, histórias, canções, impressões gustativas, olfativas, visuais -" ficam gravadas na consciência humana e se tornam parte da essência do indivíduo.

Este trabalho relata a adaptação do conto "A Sereiazinha" de Hans Christian Andersen, seguindo a proposta de ajustá-lo ao viés da Cultura Surda, objetivando vivenciar e compreender como ocorre um processo de adaptação literária, bem como contribuir com o aumento do acervo da literatura surda, que se apresenta, ainda, bastante reduzido. Desse modo, a ampliação desta modalidade, favorece ao surdo usufruir o direito à leitura dentro do seu contexto cultural, além de promover o acesso a diferentes estilos literários.

Para a realização da pesquisa investigou-se referências teóricas sobre adaptações literárias paralelamente à análise de livros adaptados para a Cultura Surda numa abordagem qualitativa. A reescrita tencionou adequar o conto "A Sereiazinha" ao âmbito da Cultura Surda sem, no entanto, trair a ideia original do autor. Para isso, no decorrer do processo, confrontou-se a teoria com as possibilidades de modificação da história, priorizando a análise dos elementos culturais passíveis de aceitação e adequação ao conto a ser adaptado.

Finalizada a reescrita do conto, discorreu-se sobre as etapas do processo: o surgimento da ideia inicial de se fazer a adaptação, as características do autor, a escolha do conto, a representatividade do mito, a adaptação finalizada, os artefatos culturais inseridos, a análise reflexiva e intencionalidade dos elementos adicionados. A pesquisa teórica durou todo o período de adaptação da história, até que as dúvidas foram esclarecidas e o processo 
finalizado. Os recursos utilizados para a adaptação do conto foram: o referencial teórico de Carvalho, Huston e Karnopp, entre outros, as obras literárias adaptadas para a cultura surda e o conto "A Pequena Sereia" de Andersen, presente na coletânea de Ana Maria Machado: Contos de Fadas de Perrault, Grimm, Andersen e outros.

\section{A adaptação de textos literários}

Na busca por embasamento teórico para o desenvolvimento deste trabalho, apesar de encontrar muitas análises de resultados de adaptações, constatou-se a carência de pesquisas relacionadas aos procedimentos e técnicas para se adaptar uma obra. Segundo Carvalho (2006) as investigações sobre a literatura infantil abrangem a natureza histórica, teórica e crítica literária, no entanto, a adaptação literária é uma modalidade de texto pouco explorada:

\footnotetext{
Ao se deixar à margem a adaptação literária como objeto de estudo, com certeza, estar-se-á marginalizando do ponto de vista histórico um dos eixos da história da literatura infantil; do ponto de vista teórico, o conhecimento de como se processa uma das formas de criação literária para crianças e jovens; e do ponto de vista crítico, deixar-se-á de avaliar essa produção que está inserida na formação de novos leitores e de verificar a sua validade (CARVALHO, 2006, p. 13).
}

Partindo da observação do autor, visualizamos os três objetivos que desejamos abordar neste trabalho: RELATAR: equivalente ao registro de uma nova faceta da obra, COMPREENDER: conhecer o processo de atualização e EXPERIENCIAR: adaptar, analisar e avaliar a relevância do resultado para o público-alvo. Portanto, os três âmbitos sugeridos por Carvalho. $\mathrm{O}$ autor afirma que a obra renovada se constitui a partir da incorporação de novos elementos e estes recursos fundamentam-se a partir de estudos teóricos focados no leitor, pois "o texto literário só sofre o processo de adaptação em virtude da especificidade do seu leitor, isto é, é a imagem desse leitor que conduz a construção desse novo texto" (CARVALHO, 2006, p. 14). Esses elementos, que caracterizam a "nova roupagem" da obra derivam das peculiaridades do público-alvo, seus costumes, sua cultura, sua língua. A adaptação objetiva refletir a identidade do novo receptor, aproximando o texto de suas vivências.

Quanto à construção do novo texto, Genette (2006, p. 20) define dois tipos de transformação de um texto: a simples ou direta que consiste em contar a mesma história de uma maneira diferente, bastando modificar algum elemento; e a transformação indireta ou por imitação, que conta uma história diferente, mas inspirada no estilo característico da original - 
"(dizer a mesma coisa de outro modo/dizer outra coisa de modo semelhante)". Assim, este trabalho aponta para uma adaptação por transformação direta, pois não tenciona criar uma narrativa diferente ao estilo da original, mas sim, remodelar as características desta, incorporando elementos pertinentes a uma nova gama de leitores. No que concerne à especificidade do leitor, Karnopp (2008) aponta relevante característica do sujeito surdo:

\begin{abstract}
Os surdos brasileiros são membros da cultura surda brasileira da mesma forma que os surdos americanos são membros da cultura surda norte-americana. Esses grupos usam línguas de sinais diferentes, compartilham experiências diferentes e possuem diferentes experiências de vida. No entanto, há alguns valores e experiências que os surdos, independente do local onde vivem, compartilham, ou seja: "todos são pessoas Surdas vivendo em uma sociedade dominada pelos ouvintes" (WILCOX; WILCOX 2005, p. 78, apud KARNOPP, 2008, p. 4).
\end{abstract}

Essa característica, pertinente a todos os surdos, é consequência da coexistência de ambas as culturas no mesmo território. Isso não molda, necessariamente, o surdo aos pilares da cultura do ouvinte, pois, apesar de torná-lo suscetível de carregar marcas da cultura dominante, sua historicidade, se desenvolve a margem dessa cultura, embora, com a participação dela. Strobel define a Cultura Surda como "o jeito de o sujeito surdo entender o mundo e de modificá-lo a fim de torná-lo mais acessível (...). Isto significa que abrange a língua, as ideias, as crenças, os costumes e os hábitos de povo surdo" (2008, p. 2). Essa cultura, segundo Karnopp (2008), não é algo isolado, mas aponta para o hibridismo, com desejo de ser reconhecida. A autora, citando Quadros e Sutton-Spence (2006), afirma que se trata de uma cultura complexa, pois seus membros interagem num ambiente multicultural e bilíngue.

O processo de adaptação literária implica inúmeros procedimentos que se distinguem conforme a exigência emancipatória da obra para adequar-se ao leitor-alvo. Transcrições para outra língua, cultura, tempo e espaço, faixa etária, são fatores que desprendem a obra das características originais para ajustar-se em novos moldes através de acréscimo, redução ou substituição de elementos, simplificação de ações ou apropriação de outros costumes.

Esta reorganização se justifica para promover o encontro da obra adaptada com o novo leitor e ocorre através das expectativas mediadas pelo adaptador (Carvalho, 2006), sendo esse seu objetivo principal e maior desafio, pois a imaginação e criatividade são particularidades intrínsecas e subjetivas do escritor, mas a incorporação de elementos exige um olhar crítico, analítico e metódico, afinal, "o que fica de um conto para uma criança é o que ele fez 
reverberar na sua subjetividade, aliado ao fato de como chegou até ela" (CORSO E CORSO, 2006, p. 29).

A prática de leitura favorece a integração e o desenvolvimento das crianças surdas, além de contribuir para a formação de sua criticidade e para aumentar a sua autonomia. A literatura voltada para crianças surdas, seja sinalizada ou impressa, impulsiona a difusão da cultura surda e traz este contato intercultural para o cotidiano de surdos e ouvintes.

Atualmente, com os avanços tecnológicos, as crianças surdas já contam com alguns projetos que favorecem o acesso à literatura infantil. São ações de incentivo à leitura com acervos que apresentam clássicos da literatura infantil narrados nas modalidades escrita, sinalizada e oral, de modo a alcançar um público mais abrangente.

A ideia de adaptar uma obra clássica para a cultura surda surgiu com a Hora do Conto, um projeto desenvolvido pela Faculdade de Letras da Universidade Federal de Goiás, UFG, sob a coordenação das professoras Sueli Maria de Regino e Alessandra Campos Lima. A expansão do projeto e do acervo de histórias proporcionaram a criação do site BIBLIOLIBRAS - Biblioteca Bilíngue de Literatura Infantil e Juvenil - Libras / Português, que objetiva viabilizar o acesso de crianças surdas e deficientes visuais à literatura Infantil e Juvenil. Também com foco na promoção da leitura, seus livros audiovisuais se adequam à proposta das escolas inclusivas e bilíngues.

Esse projeto promove o acesso de crianças surdas à literatura infantil e foi reproduzido no Programa Institucional de Bolsas de Iniciação à Docência, PIBID, em parceria com a UFG, em uma escola pública estadual de Goiânia, por alunos do curso de Licenciatura em LetrasLibras. O projeto deu aos bolsistas do PIBID a oportunidade de vivenciarem a experiência de traduzir e interpretar clássicos da literatura infantil para a Libras.

Como participante deste projeto, ao refletir sobre como seria enriquecedor para os surdos conhecerem estas mesmas histórias contadas no âmbito de sua cultura, decidi adaptar um conto de Andersen para a cultura surda. Além de promover a leitura para surdos, esses canais de comunicação visuoespacial são importantes suportes para os estudantes do curso de Letras Libras da UFG, que buscam ampliar seus conhecimentos e prática da Língua Brasileira de Sinais. 


\section{Literatura infantil e literatura surda}

Definir o conceito de Literatura tem sido quase tão complexo quanto produzi-la. "Sabe-se, pois, que, em cada época literária, são atribuídas à literatura natureza e funções distintas, condizentes com a realidade cultural e, portanto, social, da época” (PINTO, 2012, p. 5). A literatura está em constante atualização e adequação às especificidades do leitor. Resultantes desta adequação, os primeiros contos infantis tiveram sua publicação no século XVII, recolhidos da memória do povo francês, por Charles Perrault. No entanto, a literatura infantil, como gênero literário, só se constituiu definitivamente, cem anos mais tarde, com os estudos dos Irmãos Grimm, que atenuaram os eventos mais violentos e cruéis presentes nas narrativas orais. Finalmente, no século XIX, a Literatura Infantil Clássica se completa quando Andersen, guiado pelo romantismo, se torna "a primeira voz autenticamente 'romântica' a contar histórias para crianças" (COELHO, 2009, p. 27).

A Literatura Surda, porém, conforme Karnopp (2008, p. 2), não apresenta registros literários de séculos passados. Embora exista a tradição cultural de histórias contadas presencialmente, registrar essas narrativas só foi possível após a chegada da era tecnológica. Concomitantemente, cultura e literatura Surdas só ganharam evidência a partir do reconhecimento legal da Língua de Sinais. Karnopp (2008, p. 15) conceitua a Literatura Surda como produções literárias que evidenciam características da identidade e cultura surda e a presença da Língua de Sinais, mas ressalta a escassez de livros literários com narrativas que envolvam o indivíduo surdo e suas vivências. Entre os textos disponíveis, Peixoto et al (2013, p. 2), apontam três tipos de obras que compõem o artefato literário da comunidade surda: "obras traduzidas, obras adaptadas e obras criadas pelos sujeitos surdos".

O primeiro tipo abrange histórias infantis que são traduzidas para a língua de sinais com registros em vídeo. Muitos desses DVDs são disponibilizados gratuitamente pelo MEC. No segundo tipo de obra ocorre uma adaptação cultural, social e linguística da cultura ouvinte para a Cultura Surda. Esta categoria, na qual se insere o objeto de estudo deste TCC, na maioria das vezes, adapta obras clássicas da comunidade ouvinte, contadas tanto pela via oral quanto pela escrita.

A adaptação acontece através da adição, subtração ou substituição de elementos culturais sem, contudo, modificar a essência da história. São exemplos os livros: Cinderela surda, Rapunzel surda e $O$ patinho surdo, entre outras. O terceiro tipo são obras originais criadas por surdos ou membros da comunidade surda, que segundo Peixoto et al (2013, p. 2), 
"refletem a literatura surda propriamente dita", como por exemplo, as obras de Nelson Pimenta. Entre os autores estudados, foram selecionadas três obras, duas adaptadas e uma original, para análise e referência neste trabalho, sendo ambas citadas por Karnopp (2008). A primeira é o livro Cinderela Surda de Hessel, Karnopp e Rosa, baseado no clássico infantil "Cinderela", que apresenta versões de autores como Perrault, Irmãos Grimm e, mais recentemente, dos estúdios Disney.

Figura 1. Capa de Cinderela Surda

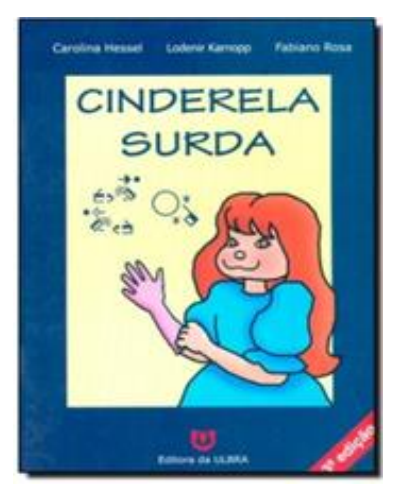

Fonte: https://www.editoraulbra.com.br/catalogo/produto/297/CINDERELA-SURDA

O livro foi escolhido por sua popularidade entre surdos e ouvintes. Na versão original o sapato é o meio pelo qual o príncipe descobre a verdadeira identidade da jovem com quem havia dançado. Na versão adaptada, tanto o príncipe quanto a Cinderela são surdos. A identidade de Cinderela é representada por um par de luvas, que simboliza a comunicação com as mãos, a Língua de Sinais, elemento cultural mais marcante na cultura Surda.

O livro traz ainda o registro em Sign Writting, uma das escritas de sinais desenvolvidas para as línguas visuoespaciais. Na história, toda a magia desaparece após a meia noite, porém as luvas permanecem inalteradas, comprovando e reafirmando a identidade da personagem. Entre as personagens, está o Mestre L’Epée, uma referência a Charles-Michel de L’Epée (1712-1789), educador francês responsável pelas primeiras oportunidades de os surdos serem educados e remete à origem francesa da Língua Brasileira de Sinais - Libras. Os autores Hessel e Rosa são surdos e professores de Língua de Sinais. Karnopp é ouvinte e intérprete. Ambos também são autores do livro Rapunzel Surda.

A segunda obra é o livro: Patinho surdo de Rosa e Karnopp, baseado no clássico infantil "O Patinho Feio", de Hans Christian Andersen, publicado pela primeira vez em 1843. 
A escolha do livro ocorreu pela relevância do autor da obra original e intensidade da narrativa. Na versão original o filhote de cisne que nasce em um ninho de patos, vive a rejeição por ser diferente. No entanto, ao crescer descobre que alcançou os padrões de beleza de sua espécie. Entre os valores morais destacam-se a busca pela aceitação, beleza interior, superação e identidade.

Figura 2. Capa de Patinho Surdo

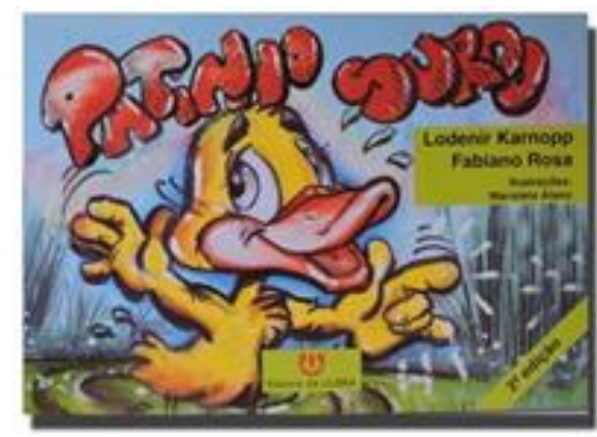

Fonte: https://www.editoraulbra.com.br/catalogo/produto/183/PATINHO-SURDO

Na versão adaptada, uma pata surda bota um ovo no ninho de cisnes e o patinho surdo nasce em meio aos cisnes ouvintes. Sentindo-se diferente, ele sai em busca de respostas e encontra uma família de patos que se comunica em Língua de Sinais, compreendendo que ali é seu verdadeiro lar. Nessa adaptação o elemento da cultura surda presente também é a Língua de Sinais. Nela ocorre uma inversão de papéis: a imagem do falso patinho feio do conto original que sofre a metamorfose para ascender como um lindo e imponente cisne, é desconstruída e substituída por um patinho verdadeiro que objetiva tão somente reencontrar suas origens e poder assumir sua identidade. As autoras, surda e ouvinte, respectivamente, se unem mais uma vez para difundir a cultura surda.

O livro: Tibi e Joca, de Cláudia Bisol, foi a terceira obra analisada. Idealizado pela autora ouvinte, com participação especial do surdo Tibiriçá Maineri, este livro é uma produção original desenvolvida para pessoas surdas. Rico em ilustrações, o livro traz a parte textual reduzida a palavras-chave que são sinalizadas por um personagem intérprete. 
Figura 3. Capa de Tibi e Joca

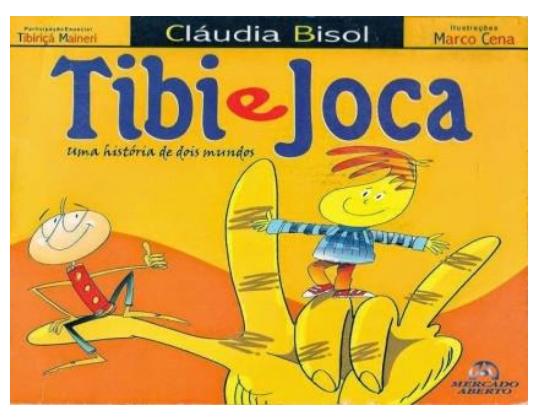

Fonte: http://www.blogvendovozes.com/2013/06/10-obras-literarias-sobre-diferencas.html

Sua seleção ocorreu diante do interesse em analisar uma obra de produção original com foco na cultura surda que representasse a categoria impressa. O livro conta a história de um surdo desde seu nascimento: a descoberta da surdez, a dificuldade de aceitação da família, a solidão e as demais barreiras vividas pelo personagem que representa a maioria dos surdos filhos de pais ouvintes. Apresenta com fidelidade a cultura surda e é ideal para crianças e jovens que não têm o domínio da leitura. A análise da obra proporcionou a possibilidade de novas reflexões sobre a necessidade do afastamento das concepções do ser ouvinte durante o processo de escrita deste projeto.

\section{O processo de adaptação}

Todas as obras derivadas de uma obra anterior, seja por imitação ou por transformação direta, são definidas por Genette (2006) como "palimpsestos". Nesse sentido, o resultado desta adaptação apresenta uma reescrita da obra original com modificações através da adição, subtração e substituição de elementos, objetivando promover a interação entre obra adaptada e leitor-alvo. Portanto, uma derivação por transformação direta.

Hans Christian Andersen (1805-1875), escritor dinamarquês e autor de contos infantis, publicou mais de 150 obras. Inspirava-se nos ideais do romantismo, exaltando a sensibilidade, os valores populares, a generosidade humana e a fé cristã. Seus contos mostram o cotidiano das pessoas, as injustiças sociais e o egoísmo do ser humano, mas também ensinam sobre a superação a partir da fé e da luta. Mundialmente conhecido como a primeira voz romântica com histórias direcionadas a crianças, “Andersen foi, sozinho, responsável por um revigoramento do conto de fadas e um alargamento de seus limites para acomodar novos desejos e fantasias". (TATAR, 2004, p. 346). 
O autor definiu seu estilo literário num momento em que as crianças começavam a ganhar reconhecimento de sua posição e condição dentro da sociedade. Suas narrativas divergem do percurso da maioria dos contos de fadas que caminham em direção ao "felizes para sempre". Em seus contos, o autor revela a realidade cotidiana às crianças. Ele ensina que é preciso lutar pelo que se deseja, mas que nem sempre é possível atingir o objetivo, entretanto, outras recompensas são alcançadas mediante suas lutas. Entre seus contos mais conhecidos foi selecionado, para a adaptação, o conto "A Sereiazinha", o qual, segundo Coelho, "explicita a ânsia de expansão do Eu, pela necessidade de conhecimento de novos horizontes e da aceitação do seu Eu pelo outro" (2009, p. 31).

Muitos clássicos infantis têm personagens inspirados em antigos mitos. Lindas e bondosas princesas, valentes príncipes, velhos reis cansados de governar, poderosas fadas e bruxas feias e más. Em boa parte das produções cinematográficas, que atualizam os contos da tradição - como a animação Shrek, na qual a princesa se transforma em ogra, ou o filme Malévola, que expõe a dualidade do bem e do mal no mesmo personagem -, essas personagens são transformadas e suas ações, subvertidas, estimulando a valorização e o respeito à diversidade humana.

Em seus contos, Andersen apresenta personagens com características que fogem ao conceito de "normalidade". Ao estilo trágico de Romeu e Julieta, o autor eternizou o amor entre dois brinquedos: $\mathrm{O}$ desafortunado soldadinho de chumbo que se equilibra sobre sua única perna para admirar a sofisticada bailarina, uma princesa a salvo em seu castelo. Esse paradoxo do universo literário infantil mostra que o autor deixa à margem o padrão frequentemente seguido, e busca representar a vida cotidiana em sua totalidade.

As metamorfoses dos personagens de Andersen, como ocorre em "O patinho feio" e "A Sereiazinha”, refletem a mutabilidade da identidade de suas criações (TATAR, 2004, p. 310). O conto "A Sereiazinha" relata a história de uma personagem híbrida que circula entre dois mundos distintos. Em troca de moldar-se ao estereótipo dos humanos ela silencia sua voz e se depara com barreiras de comunicação. Sozinha, a heroína busca a aceitação social numa luta para sobrepujar o diferente e acomodar-se numa falsa identidade enquanto desbrava novos horizontes.

As narrativas de Andersen aproximam a criança da realidade e ajudam os pequenos leitores a compreender que o mundo não é perfeito, mas é real, com ganhos e perdas, com alegrias e tristezas. As personagens de ficção são construídas a partir das singularidades dos 
seres humanos e de suas vivências em grupo. Andersen levou para seus contos maravilhosos a veracidade da vida. Para a criança surda, convivendo em meio à comunidade ouvinte e se deparando diariamente com as diferenças, é ainda maior a percepção dessa singularidade.

A luta da Sereiazinha remete a muitas das lutas enfrentadas pela criança surda na busca pela inclusão e aceitação, mostrando que as pessoas são apenas humanas, passíveis de reunir características peculiares e fora dos padrões sociais. Quanto à definição do que seja "perfeito", tudo depende de quem analisa. Nesta perspectiva, o conto "A Sereiazinha" adequou-se, com êxito, à proposta desse trabalho.

Criaturas híbridas com metade do corpo mulher e metade pássaro (Mitologia grega) ou metade peixe (Idade Média), as sereias usavam o poder sedutor de seu canto para enfeitiçar os homens no mar. No poema épico Odisseia, de Homero, Ulisses se apresenta como o primeiro homem a sobreviver ao encanto de suas vozes. No texto "O silêncio das Sereias", conto publicado em 1917, Lima (2010) observa que Kafka atualiza o mito das sereias de Homero, que silenciam o seu canto ante a indiferença do herói. Confrontadas pelo desencanto de Ulisses, elas relutam, desejando tão somente capturar seu olhar.

Foi Andersen, contudo, quem tornou uma sereia literalmente incapaz de falar. E esse feito nos inspirou a torná-la uma personagem surda, reafirmando sua mutabilidade e multiculturalismo. No entanto, ao trazer a ficção para o campo biológico, percebemos que, em ambos os casos, a personagem mantém suas cordas vocais intactas, enquanto segue em meio a transformações identitárias.

\section{O resultado do processo de adaptação}

Para desenvolver o processo de adaptação foi utilizado o conto "A Pequena Sereia”, da coletânea Contos de Fadas: de Perrault, Grimm, Andersen e outros, com seleção e apresentação de Ana Maria Machado e tradução de Maria Luiza X. de A. Borges. A metodologia utilizada para a adaptação do conto de Andersen foi a sua reescrita tendo presente a análise reflexiva dos elementos culturais passíveis de aceitação e adequação, embasados na pesquisa teórica sobre adaptações, assim como a leitura e análise de livros adaptados para surdos. Em nossa adaptação, apresentada a seguir, o conto de Andersen recebeu o título "A sereiazinha surda". 


\subsection{O conto de Andersen adaptado para a cultura surda}

Em um lugar muito distante, no fundo silencioso do mar, havia um reino onde todos eram felizes. As criaturas marinhas se comunicavam usando sinais e ninguém conhecia outra língua, com exceção da velha bruxa que morava na parte mais profunda do oceano e fazia feitiços e poções mágicas.

O rei do mar era viúvo e morava com sua mãe e seis filhas em um grande palácio rodeado de plantas aquáticas. As princesas eram seres encantados, com um corpo de mulher até a cintura, e uma cauda de peixe no lugar das pernas. As princesas tinham longas caudas e todos as admiravam por sua beleza. A Sereiazinha Surda era a mais jovem e também a mais bonita. Nada a deixava mais feliz do que ver a avó contar histórias sobre o mundo dos humanos, que elas chamavam de mundo das vozes.

A menina estava curiosa para conhecer este lugar tão diferente, onde as pessoas ouviam a própria voz e tinham pernas no lugar da cauda. Mas ela só poderia subir à superfície quando completasse quinze anos de idade, antes disso, não tinha permissão para sair do reino. Por muitos anos a caçula viu as irmãs mais velhas irem à superfície para conhecer o mundo que existia fora das águas, enquanto ela ficava no jardim do palácio admirando uma estátua de mármore que ela havia encontrado no fundo do mar. A estátua era de um rapaz alto, com expressão altiva. Suas longas pernas aumentavam o fascínio da Sereiazinha pelos humanos.

Finalmente, chegou o dia do seu décimo quinto aniversário. A Sereiazinha se despediu de sua família e nadou até a superfície do mar. Quando ergueu a cabeça sobre as ondas o sol havia acabado de se pôr, mas seus raios dourados ainda iluminavam o horizonte. O mar estava calmo e refletia o brilho das primeiras estrelas que surgiam no céu.

Perto dali, havia um navio ancorado e, dentro dele vários humanos caminhavam de um lado para o outro, organizando uma festa de aniversário. A pequena sereia notou que eles se equilibravam sobre as pernas, exatamente como sua avó contava. Um jovem príncipe de cabelos negros apareceu entre os marinheiros. No mesmo instante, centenas de fogos de artifícios explodiram no céu, formando uma cascata de luzes.

Pensando que as estrelas estavam caindo, a menina mergulhou amedrontada, mas logo voltou a erguer a cabeça para fora da água e ficou admirando o lindo príncipe, que sorria e movimentava os lábios. Eles pareciam se compreender uns aos outros, mas ninguém sinalizava nem se olhava para conversar e seus rostos expressavam pouca emoção. Então ela 
se lembrou de que naquele mundo as pessoas se comunicavam usando a voz e a audição, um sentido que o povo do reino do mar não conhecia.

De repente um raio cruzou o céu e a Sereiazinha percebeu que as estrelas haviam sumido. Uma grande tempestade começou a cair. O vento forte balançou o navio e ele afundou no mar, jogando o príncipe nas águas. A Sereiazinha nadou depressa para salvá-lo e o levou até a praia. Ele estava desacordado, mas ainda respirava. Ela observou seu rosto bem de perto e notou que ele se parecia com a estátua de mármore do jardim do palácio marinho. Alguém veio na direção deles e a Sereiazinha se escondeu atrás de uma pedra. Era uma garota humana, suas pernas eram longas e seus cabelos ondulados estavam secos e brilhantes. Ela se aproximou do príncipe, ele despertou e sorriu para ela, acreditando que aquela era sua salvadora.

Sentindo grande tristeza, a Sereiazinha voltou para casa e se sentou no jardim, perto da estátua, desejando ser como os humanos. Por muitos dias ela guardou seu segredo até que decidiu contar o que havia acontecido. Uma de suas irmãs conhecia o castelo do príncipe e a levou até lá. Desse dia em diante, todas as manhãs ela subia à superfície para observar o príncipe de longe, e seu desejo de se tornar humana crescia cada vez mais.

Certo dia perguntou se os humanos poderiam viver para sempre. E sua avó explicou: - Os humanos vivem no máximo cem anos, entretanto sua alma é imortal. Já as sereias podem viver até trezentos anos, mas quando morrem, se transformam em espuma e desaparecem no mar.

A menina queria saber se poderia se tornar humana e ter uma alma que vive para sempre. Preocupada, a avó respondeu:

- Se um homem que a ame verdadeiramente se casar com você, poderá lhe dar uma alma imortal sem perder a dele. Mas isso é impossível acontecer porque os humanos não se casam com seres de outra espécie e sua cauda a torna diferente deles.

Durante a noite, a pequena sereia não conseguiu esquecer aquela conversa. Ela daria tudo para ter pernas humanas e então, decidiu pedir ajuda à bruxa do mar.

Quando a bruxa viu a princesa já sabia o que ela queria. Preparou a poção mágica e disse que a jovem teria lindas pernas humanas e poderia caminhar graciosamente, mas em troca, teria que oferecer algo muito valioso: nunca mais poderia se comunicar usando sinais ou o encanto seria desfeito. A velha feiticeira avisou algo ainda mais terrível: 
- Se o príncipe se casar com outra mulher, ao pôr do sol do dia do casamento, você se transformará em uma estátua de pedra.

Mas a pequena Sereia desejava muito se parecer com os humanos e ter uma alma imortal. Então nadou até a praia, bem perto do castelo do príncipe e tomou a poção que trazia nas mãos. Sentiu uma dor terrível, dilacerante, enquanto via, através do reflexo da água, sua cauda se partir e formar duas pernas humanas.

Quando finalmente se equilibrou sobre as pernas, ela notou que alguém se aproximava. Olhou para o lado e o jovem príncipe lhe ofereceu a mão. Ele falava, mas ela não compreendia. Então ele a cobriu com suas vestes e a levou para seu castelo.

Por muito tempo a Sereiazinha viveu sem se comunicar. Ela estava feliz perto do príncipe, pois o amava muitíssimo, mas sentia saudades do seu mundo. Algumas vezes se sentava com o príncipe na areia da praia e ele contava seus segredos, mas ela não conseguia ler seus lábios, tampouco podia ensinar sua língua para ele. E assim, a Sereiazinha sofria ao pensar que ele nunca saberia o quanto ela o amava.

Um dia, o palácio amanheceu cheio de flores. Era dia de festa. Todos se reuniram no salão e o príncipe entrou com uma moça vestida de branco: a mesma que o encontrara na areia da praia depois do naufrágio. Eles iam se casar e a pequena sereia entendeu que havia chegado o dia de sua morte. Uma lágrima correu pelo seu rosto, mas ela não conseguia contar que era sua salvadora. Depois do casamento o príncipe foi dançar com a noiva e não viu quando a Sereiazinha saiu para a praia à espera de seu destino.

O sol se aproximava do horizonte quando ela se sentou sobre uma grande pedra à beira mar e viu a bruxa se aproximando. A velha contou que, no passado, havia tomado uma poção mágica feita por outros bruxos mais experientes e, por isso, conseguia ouvir os humanos. Ela confessou que se escondia atrás daquela pedra para ouvir o príncipe conversar com a Sereiazinha e que por várias vezes ele dissera que a amava. Apesar disso, era grato à moça que o salvou e por isso iria se casar com ela.

Feliz por saber que o príncipe a amava, a Sereiazinha sorriu e agradeceu à bruxa, sinalizando pela primeira vez depois que tomara a poção. Nesse instante o feitiço se desfez e barbatanas começaram a surgir sobre seus tornozelos. A Pequena Sereia olhou para o poente e viu que o sol desaparecia no horizonte. Nesse momento, seu corpo se transformou em uma linda estátua de bronze. 
Alguns segundos se passaram e a Sereiazinha se sentiu leve, como se flutuasse. Esticou os braços e notou sua pele translúcida. Olhou para a pedra à sua frente e viu seu corpo transformado em uma estátua. Como aquilo seria possível? Ela perguntou, assustada. E a bruxa explicou sorrindo:

- Você não se casou com o príncipe, mas ganhou uma alma imortal. Agora é um anjo bom e andará pelo mundo praticando boas ações para as crianças.

Então a Pequena Sereia teve uma ideia: iria convencer a velha bruxa a ajudá-la a ensinar a Língua de Sinais para todas as criancinhas surdas e ouvintes da terra. Quando a festa de casamento terminou o príncipe notou a ausência da Sereiazinha e foi procurá-la na praia. Somente a estátua estava lá, sobre a pedra, como uma lembrança para que ele nunca se esquecesse dela. As pequenas barbatanas nos tornozelos revelavam sua verdadeira identidade e o príncipe, finalmente, conheceu a origem da bela jovem.

A Sereiazinha encontrou vários anjos de todas as partes do mundo para ajudá-la: Regina, a rainha, com grandes habilidades para contar histórias, Maria, a grande vidente, intérprete e tradutora das Línguas de Sinais, Alessa, a fadinha que encanta quando fala com as mãos e Angel, um anjinho mensageiro que criou a escrita da Língua de Surdos. Mas isso é uma outra história...

\subsection{Artefatos Culturais: as peculiaridades da Cultura Surda}

Conforme Oliveira (2009, p. 29), no encontro entre leitor e obra, o texto precisa conter peculiaridades que o conectem ao mundo do leitor, pois esse tem valores pré-estabelecidos e, durante a leitura, alia informações conhecidas às novas, buscando compor um sentido subjetivo à essência da narrativa. Sobre essas peculiaridades, podemos compreender as vivências e os conhecimentos adquiridos e perpassados por gerações, ao longo da vida em sociedade. Esses elementos passam a compor e a representar uma cultura. Strobel (2008) denomina "artefatos culturais" as peculiaridades da cultura surda. Sobre o uso do termo "artefatos", a autora esclarece:

A maioria dos sujeitos estão habituados a apelidar de "artefatos" os objetos ou materiais produzidos pelos grupos culturais, de fato, não são só formas de cultura materiais, ou produtos definidos da mão de obra humana; também podem incluir "tudo o que se vê e sente" quando se está em contato com a cultura de uma comunidade, tais como materiais, vestuário, maneira pela qual um sujeito se dirige a outro, tradições, valores e normas, etc.

Segundo constatamos em diversos autores nos campos dos estudos culturais, o conceito "artefatos" não se referem apenas a materialismos culturais, mas àquilo que 
na cultura constitui produções do sujeito que tem seu próprio modo de ser, ver, entender e transformar o mundo.

Traço em todos os sujeitos humanos seria o fato de que somos todos artefatos culturais e, assim, os artefatos ilustram uma cultura (2008, p. 37).

Com base nesses argumentos, compreendemos "artefatos" como os elementos que constituem e definem a cultura surda. A seguir, discorremos sobre os artefatos, ou elementos, que contribuíram para o resultado final desta adaptação.

\subsection{Apontamentos das adições, subtrações e substituição de elementos}

O reino do mar, constituído por ouvintes, no conto original, dá lugar ao reino surdo, na adaptação, representando o povo surdo. Esta substituição favorece a ênfase ao artefato familiar da cultura surda, no qual a personagem se apresenta como surda filha de pais surdos, não sendo essa situação vista como um problema social, pois ser surda, como os demais familiares, é motivo de orgulho e alegria.

$\mathrm{O}$ artefato linguístico, elemento fundamental da cultura surda, surge quando a Sereiazinha incorpora a personagem surda e faz uso da Língua de Sinais. Já a experiência visual, que reflete o modo como o surdo percebe o mundo, é ressaltada durante a cena no navio, observada pela personagem.

As histórias da avó, narradas oralmente no conto original, são substituídas por histórias sinalizadas, enfatizando a literatura surda, que traduz memórias das vivências surdas e a identidade surda através do uso da língua visuo espacial. Já a comunidade ouvinte mantém-se representada pelo mundo das vozes.

\subsection{Análise reflexiva do resultado e intencionalidade dos elementos adicionados}

Seguem algumas das reflexões sobre os elementos culturais e não culturais inseridos na adaptação, bem como os objetivos que se pretendeu alcançar durante o processo de escrita. Entre essas modificações discorremos sobre: o título, o reino surdo, a barganha, a poção da audição, barbatanas, estátua e anjos.

O título Sereiazinha Surda propõe uma prévia do conteúdo da narrativa e estimula a curiosidade, incitando a criança a buscar, na personagem surda, referenciais identitários que apontem semelhanças entre suas vivências cotidianas e o universo ficcional da adaptação. 
Podemos compreender que uma comunidade composta por uma população inteira de surdos representaria uma evolução biológica por adaptação ao ambiente, neste caso, aquático, desprezando a audição, sentido menos relevante no fundo do mar. Os costumes e a cultura de um povo se constroem através da evolução de sua história. Karnopp (2008) visualiza a cultura surda como híbrida, fronteiriça, o ponto onde algo começa a se fazer presente. Dessa maneira, ser surdo não deve ser entendido como a falta da audição e da fala desenvolvida, mas como a presença da língua de sinais, de uma literatura própria, da experiência visual e vários outros elementos que compõem o contexto da pessoa surda.

A voz é a característica mais atraente da sereia de Andersen, e por isso motiva a cobiça da bruxa. No universo da Sereiazinha Surda, a Língua de Sinais é o artefato cultural naturalmente adequado para a substituição desses sentidos. A proibição da sinalização, como moeda de barganha, remete à opressão sofrida pelos surdos, em 1880, durante o congresso de Milão: o direito à instrução apenas se condicionado às regras do oralismo.

Com a substituição da percepção auditiva pela visuo espacial, a personagem surda precisa de um canal de comunicação entre os dois mundos, para não ficar alheia aos fatos durante toda a história. A poção da audição ofertada à velha bruxa faz inferência à reparação clínica da surdez através dos aparelhos auditivos e implantes cocleares. Assim, personificar a bruxa em intérprete libertou a Sereiazinha Surda do silêncio e a incitou a revelar sua identidade.

Símbolo de Copenhague, a estátua da Pequena Sereia exibe suas barbatanas aos dinamarqueses e turistas há mais de cem anos. Ela mantém o conto de Andersen vivo na memória do povo. É a reafirmação da representatividade literária do autor. Na adaptação, a reversão do feitiço, diante da sinalização espontânea da personagem surda, revela sua origem, mascarada pela falsa humanidade de suas formas, sugerindo uma analogia ao surdo oralizado.

Ser transformada em espuma e desaparecer no mar remete a um prelúdio de esquecimento. Com a substituição desse elemento pela transformação em estátua pretendeu-se paralisar o momento de metamorfose em que a personagem transita entre duas identidades, visando representar a constante flexibilidade do surdo entre duas ou mais culturas e visualizálo como um indivíduo multicultural, com uma cultura própria, mas construída em meio aos costumes dos ouvintes.

A personagem central da adaptação tem o compromisso de representar o surdo e a surdez. Os anjos adicionados na narrativa referem-se a quatro "anjos" que trabalham em prol 
da educação e da promoção de leitura, voltadas para a comunidade surda - Sueli Maria de Regino, Mariá Rezende, Alessandra Campos e Mariângela Estelita Barros - e tencionam simbolizar as conquistas alcançadas atualmente e o compromisso da sociedade com essa causa.

O conto "A Sereiazinha" apresenta inúmeras características que remetem ao universo do surdo: um ambiente que privilegia a comunicação não oral; a dificuldade de comunicação da personagem central; a transição da personagem entre dois ambientes distintos. Essas características, que estavam implícitas na história original, foram enfatizadas na adaptação e adequadas ao contexto do surdo, mostrando a história de uma jovem surda, feliz em sua comunidade, mas que vive as dificuldades de se inserir numa sociedade com costumes e valores diferentes. Por isso, ela busca meios para alcançar seus objetivos e quebrar as barreiras culturais. O resultado, portanto, traz a reorganização de um conto clássico que propõe ao leitor alvo identificar-se e sentir-se representado pela personagem principal e sua cultura.

\section{Conclusão}

A ampliação de oferta de produções e adaptações literárias para a cultura surda auxiliará, certamente, a formação da identidade do sujeito surdo através do prazer pela leitura, além de proporcionar às crianças ouvintes o conhecimento e a formação de opinião a respeito de outra cultura com a qual essa sociedade convive, mas desconhece. A literatura surda deveria ser difundida nas escolas, entre crianças surdas e ouvintes, pois contribuiria para o seu desenvolvimento social. Ao referir-se aos benefícios da leitura, Huston afirma que:

\footnotetext{
Através da leitura, e através da identificação que ela proporciona com personagens de épocas, meios e culturas diferentes, acabamos ganhando distanciamento em relação à identidade que recebemos. Assim, nos tornamos mais aptos a decifrar outras culturas e nos identificar com as pessoas que as compõem (2010, p. 128).
}

Assim, a produção formal e a propagação da literatura surda são meios pelos quais os surdos podem fazer-se conhecer como um grupo cultural com identidade própria, independente da cultura ouvinte. Acreditamos nesse caminho, talvez o mais curto e seguro para se alcançar equidade em relação ao bilinguismo. $\mathrm{O}$ processo de adaptação desenvolvido neste trabalho objetivou contribuir para o aumento do acervo da literatura para surdos - e por que não para ouvintes? - no intuito de equilibrar as duas culturas, valorizando 
cada uma nas suas características e desejando que ambas se complementem em prol do multiculturalismo.

\begin{abstract}
This work describes the process of adaptation of Andersen's tale "The Little Mermaid", conforming to the proposal of adjusting it to the context of deaf culture. This research's main goal was to experience the process of literary adaptation to better understand it. We also looked to collaborate with the extension of the collection of Deaf Literature, which is still too reduced, with the production of a new text. The main theoretical references were Carvalho, Huston and Karnopp. The methodology was based on this theoretical referential and in the analysis of other works previously adapted into the Deaf Culture. By the end, we concluded that new productions from Deaf Literature, as well as their propagation, favor the acknowledgement of the deaf as a cultural group with their own identity.
\end{abstract}

Keywords: Deaf literature. Andersen. Literary adaptation.

\title{
Referências
}

BETTELHEIM, B. A psicanálise dos contos de fadas. Trad. Arlene Caetano. $16^{\mathrm{a}}$ Ed. Rio de Janeiro: Paz e terra, 2002.< https://docero.com.br/doc/xv8cs>. Acesso em : 03 jul. 2018.

BISOL, C. Tibi e Joca: uma história de dois mundos. Porto Alegre - RS: Mercado Aberto, 2001.

CARVALHO, D. B. A. de. A adaptação literária para crianças e jovens: Robson Crusoé no Brasil. Porto Alegre: PUCRS, set/2006. Disponível em: <http://tede2.pucrs. br/tede2/handle/tede/2118 >. Acesso em: 3 jul. 2018.

COELHO, Nelly Novais. O conto de fadas: símbolos - mitos - arquétipos. $2^{\mathrm{a}}$ ed. São Paulo: Paulinas, 2009.

CORSO, D. L.; CORSO, M.. Fadas no divã: psicanálise nas Histórias Infantis. Disponível em: <http://politicaedireito.org/br/wp-content/uploads/2017/02/Fadas-no-Diva-PsicanaliseNas-Diana-Lichtenstein-1.pdf> Acesso em: 25 jun 2018.

GENETTE, Gerard. Palimpsestos: a literatura de segunda mão. Belo Horizonte - MG: Viva voz, 2010. Disponível em: <http://paginapessoal.utfpr.edu.br/cantarin/literatura-e-m-meiosdigitais-ppgel/11-de-abril/Palimpsestos\%20-G.\%20Genette-\%20em\%20portugues.pdf/at_dow nload/file>. Acesso em: 4 jul. 2018.

HESSEL, C.; KARNOPP, L.; ROSA, F. Cinderela surda. $2^{\text {a }}$ ed. Canoas - RS: Ulbra, 2007. 
HUSTON, Nancy. A espécie fabuladora: um breve estudo sobre a humanidade. Trad.Ilama Heineberg. Porto Alegre, RS: L\&PM. 2010.

LIMA, L. C. Mimesis e a reflexão contemporânea. Org. Luiz Costa Lima. Rio de Janeiro: EdUERJ, 2010.

KARNOPP, L. Literatura surda. Florianópolis: UFSC, 2008. Disponível em: $<$ http://www.libras.ufsc.br/colecaoLetrasLibras/eixoFormacaoEspecifica/literaturaVisual/asse ts/369/Literatura_Surda_Texto-Base.pdf >. Acesso em: 17 jul 2018.

MACHADO, A. M. Contos de fadas : de Perraut, Grim, Andersen e outros. Trad. Maria Luiza X. de A. Borges, Rio de Janeiro: Zahar, 2010.

OLIVEIRA, V. B. M. B. de. A representação da criança nos contos de Hans Christian Andersen: o desvelar de um paradigma, 2009. Disponível em: <http://www.ple.uem.br/defesas/pdf/vbmboliveira.pdf> Acesso em: 02 out. 2018.

PEIXOTO, J. A.; PEIXOTO, R. L.; ALBUQUERQUE, K. M. C.; SOUSA, L. J. G. de; GUIMARÃES, P. N. Tradução de obras literárias para a Libras: uma tradicão cultural necessária na comunidade surda. XIV ENEX, UFPB, 2013. Disponível em: <http://www.prac.ufpb.br/enex/trabalhos/2CCHLADLVPROBEX2013519.pdf>. Acesso em: 17 jul 2018.

PINTO, J. S. Texto literário e formação crítica do aluno. Revista Eventos Pedagógicos v.3, n.1, Número Especial, p. 447 - 454, Abr. 2012. Disponível em: <sinop.unemat.br/projetos/revista/index.php/eventos/article/download/584/397>. Acesso em: 02 out. 2018.

ROSA, F.; KARNOPP, L. Patinho surdo. Ilustrações de Maristela Alano. Canoas - RS: ULBRA, 2005.

STROBEL. Karin. As imagens do outro sobre a cultura surda. Florianópolis, SC: UFSC. 2008.

TATAR, M. Contos de fadas: edição comentada e ilustrada. 2002. Trad. Maria Luiza X. de A. Borges, Rio de Janeiro: Zahar, 2004. Disponível em: 〈https://docero.com.br/doc/x8n0s〉 Acesso em: 11 jul 2018.

WILCOX, Sherman; WILCOX, Phyllis. Aprender a ver. Trad.: Tarcísio Leite. Rio de Janeiro: Arara Azul, 2005. 
Submetido em 17 de dezembro de 2017. Aceito em 02 de junho em 2019.

Publicado em 19 de setembro de 2019. 